\title{
Expression and function of the ghrelin axis, including a novel preproghrelin isoform, in human breast cancer tissues and cell lines
}

\author{
$P$ L Jeffery, $R$ E Murray, A H Yeh, J F McNamara, $R P$ Duncan, G D Francis, \\ $A C$ Herington and $L K$ Chopin
}

Ghrelin Research Group, Hormone-dependent Cancer Programme, School of Life Sciences, Queensland University of Technology, PO Box 2434, Brisbane 4001, Australia

(Requests for offprints should be addressed to P Jeffery; Email: p.jeffery@student.qut.edu.au)

\begin{abstract}
While oestrogen, progesterone and growth factors, including growth hormone $(\mathrm{GH})$, are clearly implicated in the pathogenesis of breast cancer, there is now evidence that the newly described ghrelin axis is also involved. The aims of this study were to investigate the expression of the ghrelin axis in breast cancer tissues and cell lines and to examine the effect of ghrelin on breast cancer cell proliferation in vitro. Ghrelin and its functional receptor, the growth hormone secretagogue receptor (GHSR) type 1a, were expressed in normal breast tissue and breast cancer specimens and cell lines. In contrast, the truncated GHSR type $1 \mathrm{~b}$ isoform was exclusively expressed in breast carcinoma, suggesting that it has potential as a diagnostic marker. Ghrelin treatment significantly increases the proliferation of the MDA-MB-435 and MDA-MB-231 breast cancer cell lines in vitro. In addition, we have described the expression of a human preproghrelin isoform, exon 3-deleted preproghrelin, which encodes mature ghrelin plus a novel C-terminal peptide. Quantitative RT-PCR was used to demonstrate that this mRNA isoform is highly expressed in the MDA-MB-435 metastatic breast cancer cell line relative to the benign MCF-10A breast epithelial cell line. The unique C-terminal peptide of exon 3-deleted preproghrelin is expressed in the glandular epithelium of breast cancer tissues, with high-grade carcinoma exhibiting the strongest immunoreactivity. The data presented here suggest that components of the ghrelin axis may represent novel markers for breast cancer and potential therapeutic targets.
\end{abstract}

Endocrine-Related Cancer (2005) 12 839-850

\section{Introduction}

Breast cancer is the most commonly diagnosed malignancy in Western women (Jemal et al. 2004) and is a significant cause of mortality and morbidity. Ovarian hormones and their receptors are essential for normal mammogenesis and the initiation and progression of breast cancer (Anderson \& Clarke 2004). Growth factors, however, also influence normal and pathological breast development (Laban et al. 2003), and there is emerging evidence that the endogenous growth hormone secretagogue, ghrelin, plays a role in breast cancer.
Mature ghrelin, a 28 amino acid peptide hormone, is post-translationally modified to give rise to a unique $n$-octanoylated peptide, which stimulates growth hormone (GH) release (Kojima et al. 1999). The cognate receptor for ghrelin, the growth hormone secretagogue receptor (GHSR), has two documented splice variants, producing the functional type $1 \mathrm{a}$ receptor and a truncated type $1 \mathrm{~b}$ receptor (Howard et al. 1996). A non-acylated form of ghrelin (des-acyl ghrelin) does not activate the GHSR or induce GH release (Hosoda et al. 2000) but appears to have actions which are independent of the GHSR (Ariyasu et al. 2005). We have recently characterised an exon 4-deleted 
preproghrelin mRNA isoform in mouse tissues, which is translated to produce a truncated proghrelin peptide possessing a unique carboxy terminus (Jeffery et al. 2005), and we have previously identified a homologous human isoform (exon 3-deleted preproghrelin) in prostate cancer cell lines (Jeffery et al. 2002, 2003).

Ghrelin is ubiquitously expressed in the body, suggesting that it possesses wide-ranging physiological functions, aside from stimulation of $\mathrm{GH}$ release. Its actions include a role in appetite regulation and obesity (Wren et al. 2001), while the evidence regarding its influence on adipogenesis is contradictory (Zhang et al. $2004 a$ ). Energy homeostasis is directly associated with reproductive function and the importance of ghrelin in a range of reproductive processes, including steroid hormone regulation and embryo development, has recently been demonstrated (Barreiro \& Tena-Sempere 2004).

Ghrelin expression has been detected in many endocrine tumour types (Kanamoto et al. 2001, Korbonits et al. 2001, Papotti et al. 2001, Iwakura et al. 2002, Arnaldi et al. 2003, Corbetta et al. 2003, Volante et al. 2003, Tsolakis et al. 2004) and hormone-dependent cancers including testicular tumours (Gaytan et al. 2004). At the functional level, $n$-octanoylated ghrelin treatment increases the rate of proliferation in a number of cell lines, including human prostate cancer (Jeffery et al. 2002), HepG2 hepatoma (Murata et al. 2002) and pancreatic adenocarcinoma cancer cell lines (Duxbury et al. 2003), rodent pituitary tumour cells (Nanzer et al. 2004), as well as some normal cell lines and primary cell cultures (Pettersson et al. 2002, Andreis et al. 2003, Kim et al. 2004, Mazzocchi et al. 2004, Zhang et al. 2004b, Maccarinelli et al. 2005). There is evidence to suggest that a similar system could exist in female hormone-dependent cancers, such as breast cancer. While normal human breast tissue does not exhibit specific binding sites for synthetic growth hormone secretagogues (Papotti et al. 2000), binding activity has been described in neoplastic breast tissues and in breast cancer cell lines (Cassoni et al. 2001). However, GHSR 1a expression has not been demonstrated in these cell lines.

Ghrelin treatment resulted in an anti-proliferative response in these cell lines in vitro, although this occurred at relatively high $(1000 \mathrm{nM})$ concentrations (Cassoni et al. 2001). This contrasts with our previous studies in prostate cancer cell lines, where proliferation was maximally stimulated at $10 \mathrm{nM}$ ghrelin and inhibition of proliferation was not observed (Jeffery et al. 2002).

The present study aimed to investigate (a) the expression of the ghrelin axis, including the novel exon 3-deleted preproghrelin isoform, in breast cancer cell lines and tissues and (b) the effect of ghrelin treatment on breast cancer cells in vitro, in order to determine if an autocrine/paracrine pathway exists to promote cell growth in breast cancer, as appears to be the case in prostate cancer (Jeffery et al. 2002).

\section{Materials and methods}

\section{Cell culture}

Oestrogen-dependent breast cancer cell lines T47D and MCF-7, the oestrogen-independent cell lines MDAMB-231 and MDA-MB-435, and the transformed benign breast epithelial cell line, MCF-10A (Soule et al. 1990), were obtained from the American Type Culture Collection (ATCC, Rockville, MD, USA). While microarray studies showing that the MDA-MB435 cell line clustered with melanoma cells (Ellison et al. 2002) had previously cast doubt on the derivation of this cell line, MDA-MB-435 cells are indeed a breast epithelial cell line and not derived from occult melanoma (Sellappan et al. 2004). All cell lines were cultivated in DMEM/F12 medium (Invitrogen, Carlsbad, CA, USA) containing $10 \%$ foetal calf serum (FCS; Invitrogen), $50 \mathrm{U} / \mathrm{ml}$ penicillin, $50 \mu \mathrm{g} / \mathrm{ml}$ streptomycin and $5 \mu \mathrm{g} / \mathrm{ml}$ gentamicin (Invitrogen) and grown in tissue culture flasks (Nagle Nunc International, Roskilde, Denmark) in a $5 \% \quad \mathrm{CO}_{2}$ atmosphere at $37^{\circ} \mathrm{C}$. Cells were free of Mycoplasma infection (ATCC Mycoplasma detection kit).

\section{RNA extraction and reverse transcription- polymerase chain reaction (RT-PCR)}

On reaching $70 \%$ confluency, cultured cells were collected and total RNA was extracted using Trizol (Invitrogen), according to the manufacturer's instructions, and then treated with DNase (DNA free, Ambion, Austin, TX, USA). For reverse transcription, $0.5 \mu \mathrm{g} / \mu \mathrm{l}$ oligo dT18 primer was added to $5 \mu \mathrm{g}$ total RNA and incubated for $10 \mathrm{~min}$ at $70^{\circ} \mathrm{C}$. First strand buffer, to a final concentration of $50 \mathrm{mM}$ TrisCl (pH 8.3), $75 \mathrm{mM} \mathrm{KCl}, 3 \mathrm{mM} \mathrm{MgCl}_{2}, 10 \mathrm{mM}$ dithiothreitol (Invitrogen) and $300 \mu \mathrm{M}$ of each dNTP (pH 7; Roche, Basel, Switzerland), was added and incubated with 10 units/ $\mu$ l SuperScript RT II (Invitrogen) at $43{ }^{\circ} \mathrm{C}$ for $90 \mathrm{~min}$. In order to test for genomic DNA contamination (critical for the valid detection of GHSR 1b, which contains intronic sequence) and to check the integrity of the cDNA, RT-PCR for $\beta_{2}$ microglobulin was performed (Table 1). Normal human breast and stomach RNAs were purchased from Clontech (Palo Alto, CA, USA). For real-time 
Table 1 Primer sequences, expected amplicon sizes (bp) and annealing temperatures (Ta) for RT-PCR

\begin{tabular}{|c|c|c|c|}
\hline RT-PCR primer pair & Primer sequence & Size (bp) & $\mathrm{Ta}\left({ }^{\circ} \mathrm{C}\right)$ \\
\hline \multicolumn{4}{|l|}{ Full-length preproghrelin } \\
\hline $\begin{array}{l}\text { sense } \\
\text { antisense }\end{array}$ & $\begin{array}{l}\text { 5'GCCCACCTGTCTGCAACC } 3^{\prime} \\
\text { 5'TGAACATTTATTCGCCTCCTG3' }\end{array}$ & 501 & 50 \\
\hline \multicolumn{4}{|c|}{ Exon 3-deleted preproghrelin } \\
\hline $\begin{array}{l}\text { sense } \\
\text { antisense }\end{array}$ & $\begin{array}{l}\text { 5'AACTGGAAGTCCGGAGGCCCC } 3^{\prime} \\
\text { 5'GAACATTTATTCGCCTCCTG3' }^{\prime}\end{array}$ & 151 & 62 \\
\hline \multicolumn{4}{|l|}{ GHSR 1a } \\
\hline $\begin{array}{l}\text { sense } \\
\text { antisense }\end{array}$ & $\begin{array}{l}\text { 5'TCTTCCTTCCTGTCTTCTGTC3' } \\
\text { 5'AGTCTGAACACTGCCACC } 3^{\prime}\end{array}$ & 349 & 50 \\
\hline \multicolumn{4}{|l|}{ GHSR 1a nested } \\
\hline $\begin{array}{l}\text { sense } \\
\text { antisense }\end{array}$ & $\begin{array}{l}\text { 5'ACCAGAACCACAAGCAAACC } 3^{\prime} \\
\text { 5'TGATGGCAGCACTGAGGTAG3' }\end{array}$ & 192 & 50 \\
\hline \multicolumn{4}{|l|}{ GHSR 1b } \\
\hline $\begin{array}{l}\text { sense } \\
\text { antisense }\end{array}$ & $\begin{array}{l}\text { 5'TCTTCCTTCCTGTCTTCTGT3' } \\
\text { 5'GATAGGACCCGCGAGAGAAA3' }\end{array}$ & 179 & 55 \\
\hline $\begin{array}{l}\beta_{2} \text { microglobulin } \\
\text { sense } \\
\text { antisense }\end{array}$ & $\begin{array}{l}\text { 5'TGAATTGCTATGTGTCTGGGT3' } \\
\text { 5'CCTCCATGATGCTGCTTACAT3' }\end{array}$ & 248 & 50 \\
\hline
\end{tabular}

Table 2 Primer sequences, expected amplicon sizes (bp) and annealing temperatures (Ta) for quantitative real-time RT-PCR

\begin{tabular}{|c|c|c|c|}
\hline qRT-PCR primer pair & Primer Sequence & Size (bp) & $\mathrm{Ta}\left({ }^{\circ} \mathrm{C}\right)$ \\
\hline \multicolumn{4}{|l|}{ Full-length preproghrelin } \\
\hline $\begin{array}{l}\text { sense } \\
\text { antisense }\end{array}$ & $\begin{array}{l}5^{\prime} \text { CCCTTTGATGTTGGAATCAAGCT } 3^{\prime} \\
5^{\prime} \text { GGGCCTCTTTGGCCTCTTC } 3^{\prime}\end{array}$ & 106 & 60 \\
\hline \multicolumn{4}{|c|}{ Exon 3-deleted preproghrelin } \\
\hline $\begin{array}{l}\text { sense } \\
\text { antisense }\end{array}$ & $\begin{array}{l}5^{\prime} \text { CCAGCAGAGAAAGGAGTCGAAGA } 3^{\prime} \\
5^{\prime} \text { GGCCTCCGGACTTCCAGTT } 3^{\prime}\end{array}$ & 126 & 60 \\
\hline \multicolumn{4}{|l|}{$18 \mathrm{~S}$ rRNA } \\
\hline $\begin{array}{l}\text { sense } \\
\text { antisense }\end{array}$ & $\begin{array}{l}5^{\prime} \text { TTCGGAACTGAGGCCATGAT 3' } \\
5^{\prime} \text { CGAACCTCCGACTTTCGT 3' }\end{array}$ & 151 & 60 \\
\hline
\end{tabular}

RT-PCR, reverse transcription was performed on RNA using the AMV first-strand cDNA synthesis kit (Invitrogen) as previously described (Jeffery et al. 2005).

RT-PCR was performed to investigate the expression of preproghrelin, exon 3-deleted preproghrelin and the type $1 \mathrm{a}$ and $1 \mathrm{~b}$ transcripts of the GHSR in the MCF-7, MDA-MB-231, MDA-MB-435 and T47D breast cancer cell lines, and in the positive control tissue, human stomach. To detect preproghrelin mRNA transcripts, RT-PCR was performed using primer pairs specific for the full-length preproghrelin transcript and for exon 3-deleted preproghrelin (Table 1). For the detection of GHSR 1a, nested PCR was performed. The outer primers were used in the first reaction and $5 \mu \mathrm{l}$ of this product was reamplified using the nested primers (Table 1). As GHSR $1 b$ cDNA is identical to the genomicDNA, RNA was treated with DNase prior to reverse transcription and a 'no reverse transcription' control was included. In all PCRs, a negative 'no template' control was also included. PCRs contained PCR buffer, $2.5 \mathrm{mM} \mathrm{MgCl} 2,300 \mu \mathrm{M}$ of each dNTP, $2 \mu \mathrm{l}$ cDNA, 1 unit Red Hot Polymerase (Integrated Sciences, Melbourne, Australia) and relevant PCR primers (Proligo, Armidale, Australia) (Table 1). Thermal cycling, performed using a PTC-200 DNA engine (MJ Research, Watertown, MA, USA) consisted of an initial denaturation at $94^{\circ} \mathrm{C}$ for $5 \mathrm{~min}$, followed by 40 cycles of $94^{\circ} \mathrm{C}$ for $30 \mathrm{~s}$, annealing temperature (Table 1) for $30 \mathrm{~s}$ and $72^{\circ} \mathrm{C}$ for $2 \mathrm{~min}$ and a final extension of $72^{\circ} \mathrm{C}$ for $10 \mathrm{~min}$. PCR products were excised from the gel and purified (Concert Rapid Gel PCR purification kit, Invitrogen). Automatic sequencing was undertaken at the Australian Genome Research Facility (Brisbane, Australia) using Applied Biosystems Big Dye 3.1 (Applied Biosystems, Foster City, CA, USA). 


\section{Real-time quantitative RT-PCR}

The Applied Biosystems (ABI) 7000 Prism Real Time PCR Sequence detection system was used to determine relative expression levels of full-length preproghrelin and exon 3-deleted preproghrelin, in the epithelial cell line MCF-10A and in the MCF-7, MDA-MB-231 and MDA-MB-435 breast cancer cell lines. All primers were designed using the Primer Express version 2.0 software (ABI), synthesised by Proligo (Table 2), and validated to ensure that the efficiencies of the target and reference genes were similar (User Bulletin \#2, ABI Prism 7000 Sequence detection system). Each PCR contained $10 \mu \mathrm{l} 2 \times \mathrm{SYBR}^{\mathbb{R}}$ green master mix (ABI), $200 \mathrm{nM}$ of each primer and $5 \mu \mathrm{l}$ cDNA. All PCRs were performed in triplicate and normalised against the reference primer set (18S rRNA, Table 2). Data were analysed using the comparative $\mathrm{C}_{T}$ method (User Bulletin \#2, ABI) and were represented as foldchange as compared with the calibrator cell line (MCF$10 \mathrm{~A})$.

\section{Antibodies and tissue samples}

Polyclonal anti-GHSR 1a, anti-GHSR 1b, anti-ghrelin and anti-exon 3-deleted preproghrelin antibodies were raised in rabbits (Institute for Medical and Veterinary Sciences, Adelaide, Australia) against peptide fragments synthesised by Mimotopes (Melbourne, Australia). Peptide fragments for GHSR 1a (RAWTESSINTC) (Feighner et al. 1998), GHSR $1 \mathrm{~b}$ (GGSQRALRLSLAGPILSLC), mature n-octanoylated ghrelin (GSSFLSPEHQRVQQRKESKKPPAKLQPRC) and the unique C-terminal peptide derived from exon 3deleted preproghrelin (RPQPTSDRPQALLTSLC) were conjugated to diptheria toxin (Mimotopes) and antibodies raised separately in rabbits. Rabbit serum was affinity purified and antibodies were characterised by ELISA and Western analysis (Jeffery et al. 2002). The specificity of each antibody was also tested with stringent controls, including preabsorption of each antibody with the peptide it was raised against.

Breast cancer tissue sections were derived from excess surgical specimens from biopsies for pathological diagnosis and grading at Queensland Medical Laboratory (QML, Brisbane, Queensland, Australia), and were obtained in accordance with ethical guidelines (Queensland University of Technology ethics approval \# 2820H). Normal breast, pituitary and stomach tissue sections were obtained from the Peterborough Hospital Tissue Bank (Peterborough, UK).

\section{Immunohistochemistry on cell lines and tissues}

Immunohistochemistry on breast cancer cell lines was performed as described previously (Jeffery et al. 2002). Briefly, cells were grown to $50-70 \%$ confluency in 96-well plates (Nagle Nunc), washed in PBS and fixed for $5 \mathrm{~min}$ in ice-cold $100 \%$ methanol. Cells were washed with $1 \% \mathrm{H}_{2} \mathrm{O}_{2}$ in $50 \%$ methanol, followed by $0.3 \%$ Triton $\mathrm{X}$ in PBS and incubated with $1 \%$ bovine serum albumin (BSA) (Sigma-Aldrich Corp., St Louis, MO, USA). Purified ghrelin antibody was diluted $1 / 10$, exon 3-deleted preproghrelin antibody was diluted $1 / 100$, GHSR 1a antibody was diluted $1 / 50-1 / 100$ and GHSR $1 \mathrm{~b}$ antibody was diluted $1 / 50-1 / 100$ in $0.01 \mathrm{M}$ PBS with $1 \%$ BSA, and incubated with cells overnight. Immunohistochemistry was also performed on normal breast tissue (Peterborough Hospital Tissue Bank) and on 23 breast cancer tissue sections of clinical grades $1-3$, as described above, using an Envision Plus DAB anti-rabbit immunostaining kit (Dako, Kyoto, Japan) according to the manufacturer's instructions. Human pituitary sections for GHSR 1a and GHSR $1 \mathrm{~b}$ and human stomach for ghrelin (Peterborough Hospital Tissue Bank) were used as positive controls. For all immunohistochemical experiments, negative controls were performed by substituting immune sera with $1 \%$ BSA in $0.01 \mathrm{M}$ PBS and also by pre-absorbing each antibody overnight with $1 \mathrm{mg} / \mathrm{ml}$ peptide to which the antibody was raised. Sections were counterstained with haematoxylin (Australian Chemical Reagents, Moorooka, Australia).

\section{Cell proliferation assays (Wst-1 assays)}

MDA-MB-231, MDA-MB-435, MCF-7 and MCF$10 \mathrm{~A}$ cell lines were cultured in 96-well plates (Nagle Nunc) for $72 \mathrm{~h}$ at $37^{\circ} \mathrm{C}$ in the presence of $n$ octanoylated ghrelin peptide (Mimotopes) at concentrations ranging from 0 to $1000 \mathrm{nM}$. The culture medium contained $20 \mathrm{nM}$ 4-(2-aminoethyl) benzenesulphonyl fluoride hydrochloride (AEBSF, SigmaAldrich), a serine protease inhibitor that protects ghrelin from inactivation (Katugampola et al. 2001). Medium was changed daily, with controls receiving no treatment. At the completion of the 4-day protocol, cells were incubated for $2 \mathrm{~h}$ in Wst-1 reagent (Roche) at $37^{\circ} \mathrm{C}$ and cell proliferation was quantified by measuring photometric absorbance at $450 \mathrm{~nm}$ (BMG LABTECH, Offenburg, Germany). Each experiment provided 16 replicates and the experiment was repeated three times. 


\section{Statistics}

Statistical analyses were undertaken using SPSS software (SPSS, Chicago, IL, USA). All numerical data are presented as means \pm standard error of the mean (s.E.M.). Statistical significance was determined using one-way analysis of variance (ANOVA) with Bonferroni post-hoc analysis, with a $P$ value $<0.05$ considered to be statistically significant.

\section{Results}

\section{Expression of the ghrelin axis in breast cancer (RT-PCR)}

Expression of the ghrelin axis was investigated in the MDA-MB-231, MCF-7, MDA-MB-435 and T47D breast cancer cell lines with RT-PCR (Fig. 1). In each cell line, a cDNA product of the expected size for the full-length preproghrelin transcript $(501 \mathrm{bp})$ was observed (Fig. 1A). The exon 3-deleted variant of the preproghrelin transcript was also amplified in all of the cell lines tested (392 bp; Fig. 1A). Using RT-PCR with primers specific for the exon 3-deleted preproghrelin transcript (Table 1), with the sense primer being designed to cross the unique exon $2 / 4$ boundary, this variant was also demonstrated in all cell lines (Fig. 1B). Preproghrelin mRNA and the exon 3-deleted transcript were also detected by RT-PCR in the MCF-10A cell line and in normal breast cDNA (data not shown). mRNA for both GHSR isoforms (types 1a and $1 \mathrm{~b}$ ) was detected by RT-PCR in the MDA-MB-231, MCF-7, MDA-MB-435 and T47D cell lines (Fig. 1C

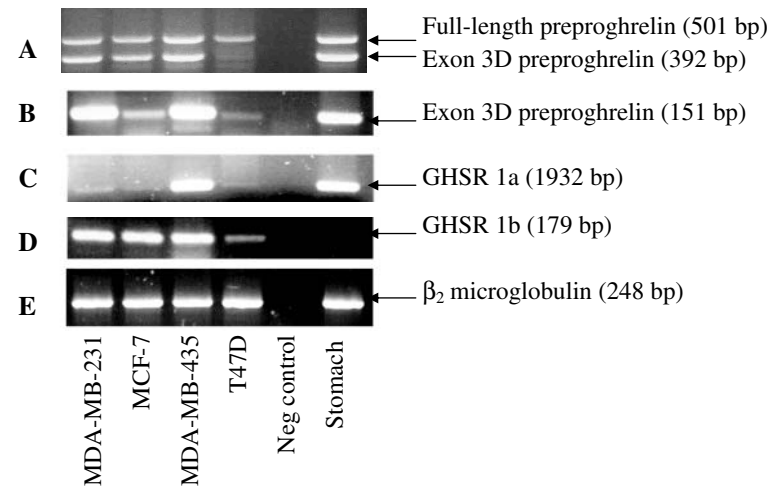

Figure 1 Representative ethidium bromide-stained agarose gels of RT-PCR products from breast cancer cell lines. (A) RT-PCR demonstrating the $m R N A$ expression of full-length preproghrelin (501 bp) in the MDA-MB-231, MCF-7, MDA-MB-435 and T47D cell lines. The lower band (392 bp) represents the exon 3-deleted mRNA variant. (B) Using primers and PCR conditions specific for the exon 3-deleted preproghrelin, $P C R$ product was detected in the MDA-MB-231, MCF-7, MDA-MB-435 and T47D cell lines. (C) GHSR type 1a was also expressed in all cell lines tested, as was the truncated GHSR $1 \mathrm{~b}$ isoform (D). All transcripts were amplified in the positive control tissue, human stomach. (E) $\beta_{2}$ microglobulin screening confirmed cDNA purity and quality.

and D), producing PCR products of expected sizes (192 and $179 \mathrm{bp}$ respectively). All transcripts were detected in the stomach positive control and the RT-PCR for $\beta_{2}$ microglobulin was also positive (Fig. 1E). The identities of all transcripts were confirmed by cDNA sequencing.

Translation of exon 3-deleted preproghrelin mRNA (Fig. 2A) results in a truncated preproghrelin, which

A

34 atg ccc tcc cca ggg acc gtc tgc agc ctc ctg ctc ctc ggc atg ctc tgg ctg $\begin{array}{lllllllllllllllllll}\mathbf{1} & \mathbf{M} & \mathbf{P} & \mathbf{S} & \mathbf{P} & \mathbf{G} & \mathbf{T} & \mathbf{V} & \mathbf{C} & \mathbf{S} & \mathbf{L} & \mathbf{L} & \mathbf{L} & \mathbf{L} & \mathbf{G} & \mathbf{M} & \mathbf{L} & \mathbf{W} & \mathbf{L}\end{array}$

88 gac ttg gec atg gca ggc tcc agc ttc ctg agc cet gaa cac cag aga gtc cag $\begin{array}{lllllllllllllllllll}19 & D & L & A & M & A & G & S & S & F & L & S & P & E & H & \mathbf{Q} & R & V & \mathbf{Q}\end{array}$

142 cag aga aag gag tcg aag aag cca cca gcc aag ctg cag ccc cga gct cta gca $\begin{array}{lllllllllllllllllll}37 & \mathbf{Q} & \mathbf{R} & \mathbf{K} & \mathbf{E} & \mathbf{S} & \mathbf{K} & \mathbf{K} & \mathbf{P} & \mathbf{P} & \mathbf{A} & \mathbf{K} & \mathbf{L} & \mathbf{Q} & \mathbf{P} & \mathbf{R} & \mathbf{A} & \mathbf{L} & \mathbf{A}\end{array}$

196 ggc tgg ctc cgc ccg gaa gat gga ggt caa gca gaa ggg gca gag gat gaa ctg

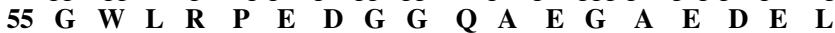

250 gaa gtc cgg agg cec cag ccg aca agt gat cgc cca caa gec tta ctc acc tct ctc taa

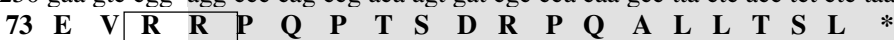

B

$\begin{array}{llllllllllllllllllllll}73 & \text { E } & \text { V } & \text { R } & \text { F } & \text { N } & \text { A } & \text { P } & \text { F } & \text { D } & \text { V } & \text { G } & \text { I } & \text { K } & \text { L } & \text { S } & \text { G } & \text { V } & \text { Q } & \text { Y } & \text { Q... }\end{array}$ 250 gaa gtc cgg ttc aac gec ccc ttt gat gtt gga atc aag ctg tca ggg gtt cag tac cag

Figure 2 Complete coding sequence of the human exon 3-deleted preproghrelin transcript. (A) Open reading frame of exon 3-deleted preproghrelin with the mature ghrelin peptide sequence underlined (accession \# AY184207). The shaded type indicates nucleotide and amino acid sequence divergence from full-length preproghrelin and the dibasic motif is boxed. Numbers indicate nucleotide locations and amino acid locations. (B) The nucleotide and peptide sequence of the corresponding C-terminal region of full-length preproghrelin (accession \# AB029434), displaying the difference between the two isoforms. 
A

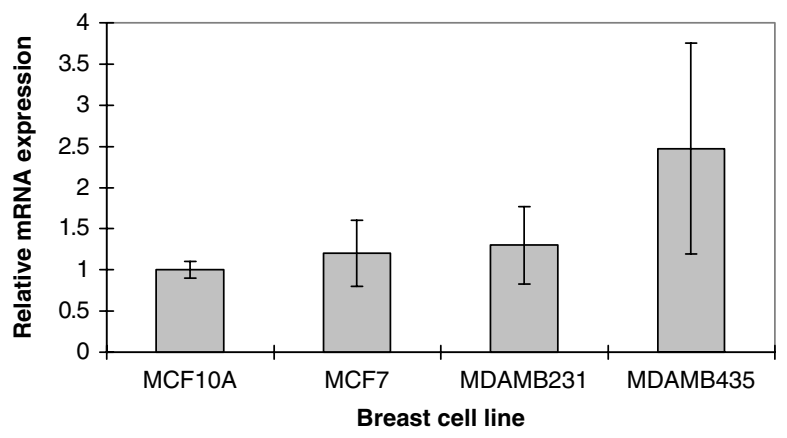

B

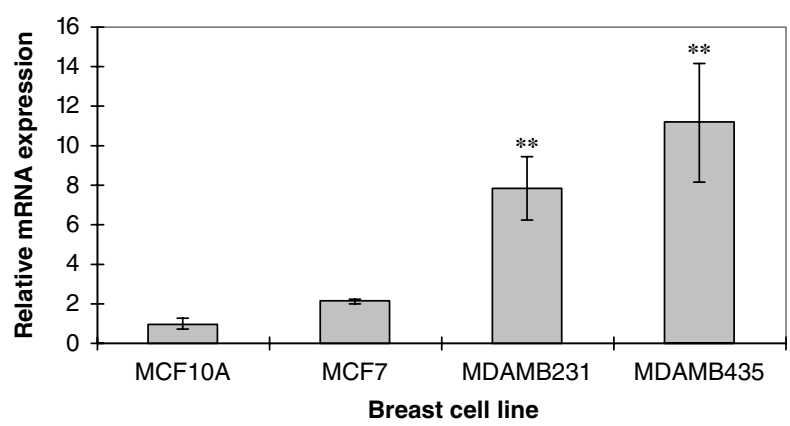

Figure 3 Real-time quantitative RT-PCR showing relative mRNA expression levels of (A) full-length and (B) exon 3-deleted preproghrelin in MCF-7, MDA-MB-231 and MDA-MB-435 cell lines. Full-length and exon 3-deleted preproghrelin mRNA levels in the MCF-10A cell line were normalised to 1. Data were expressed relative to the MCF-10A cell line mRNA levels and are represented as means \pm S.E.M. ( $n=3$ per cell line, assays performed in triplicate). ${ }^{\star \star} P<0.01$ relative to the calibrator cell line (MCF-10A).

possesses a unique $\mathrm{C}$-terminal tail composed of 16 amino acids and a dibasic (RR) motif which is not present in the corresponding full-length preproghrelin sequence (Fig. 2B). Polyclonal antibodies were raised against the variant's unique peptide tail and used to determine protein expression in breast cancer cell lines and tissues.

\section{Quantitation of full-length preproghrelin and the exon 3-deleted preproghrelin mRNA transcripts in breast cell lines by real time RT-PCR}

Expression of full-length preproghrelin mRNA and the novel exon 3-deleted preproghrelin variant mRNA was quantitated in the MCF-10A, MCF-7, MDAMB-231 and MDA-MB-435 cell lines by real-time quantitative RT-PCR analysis. For both transcripts, expression levels in the calibrator cell line (the benign breast epithelial cell line, MCF-10A) were set to 1 (Fig. 3). The relative expression level of full-length preproghrelin mRNA in the MCF-7 and the MDAMB-231 cell lines was not significantly different to expression in the MCF-10A cell line $(P>0.05)$. Although the MDA-MB-435 cell line displayed a 2.7fold increase in full-length preproghrelin transcript levels over the MCF-10A cell line (Fig. 3A), this was not statistically significant $(P>0.05)$.

The novel exon 3-deleted preproghrelin transcript was detected in all the breast cancer cell lines tested by real-time quantitative RT-PCR (Fig. 3B). There was no significant difference in the level of expression of the exon 3-deleted preproghrelin mRNA variant between the MCF-10A cell line and the MCF-7 cell line $(P>0.05)$ (Fig. 3B); however, transcript was significantly elevated in the MDA-MB-231 cell line compared with the MCF-10A cell line $(P=0.003)$ (Fig. 3B), and expression of the novel mRNA isoform was 11.2-fold higher in the aggressive, metastatic MDA-MB-435 cell line than in the non-tumourigenic MCF-10A cell line $(P=0.001)$ (Fig. 3B).

\section{Immunohistochemistry on breast histological sections}

Ghrelin immunoreactivity was observed at very low levels in the normal breast epithelium, with moderately higher levels of staining in all of the 23 breast cancer samples stained within the same immunohistochemistry experiment (Fig. 4A,B,C). Immunohistochemistry, using the anti-exon 3-deleted preproghrelin antibody specific to the C-terminal tail of the isoform, revealed weak staining of the epithelial cells of normal breast glands (Fig. 4D). A greater intensity of specific staining for this isoform was observed in grade 1 carcinoma (Fig. 4E) and grade 2 carcinoma (Fig. 4F) when compared with normal breast epithelium (Fig. 4D). The highest level of exon 3-deleted preproghrelin immunoreactive staining, indicating high protein expression of the unique isoform, was detected in grade 3 breast carcinoma specimens (Fig. 4G). Up-regulated expression of the isoform was observed in all breast cancer tissues examined. Cytoplasmic GHSR 1a immunoreactivity was observed in normal breast tissue (data not shown) and in the glandular epithelium of grades 1, 2 and 3 breast cancers (Fig. 4I,J,K). The GHSR type $1 \mathrm{~b}$ isoform was highly expressed in the epithelium of all breast cancer tissues examined, as demonstrated by intense immunostaining in a representative sample (Fig. 4L), whilst normal breast tissues failed to show specific immunoreactivity, 

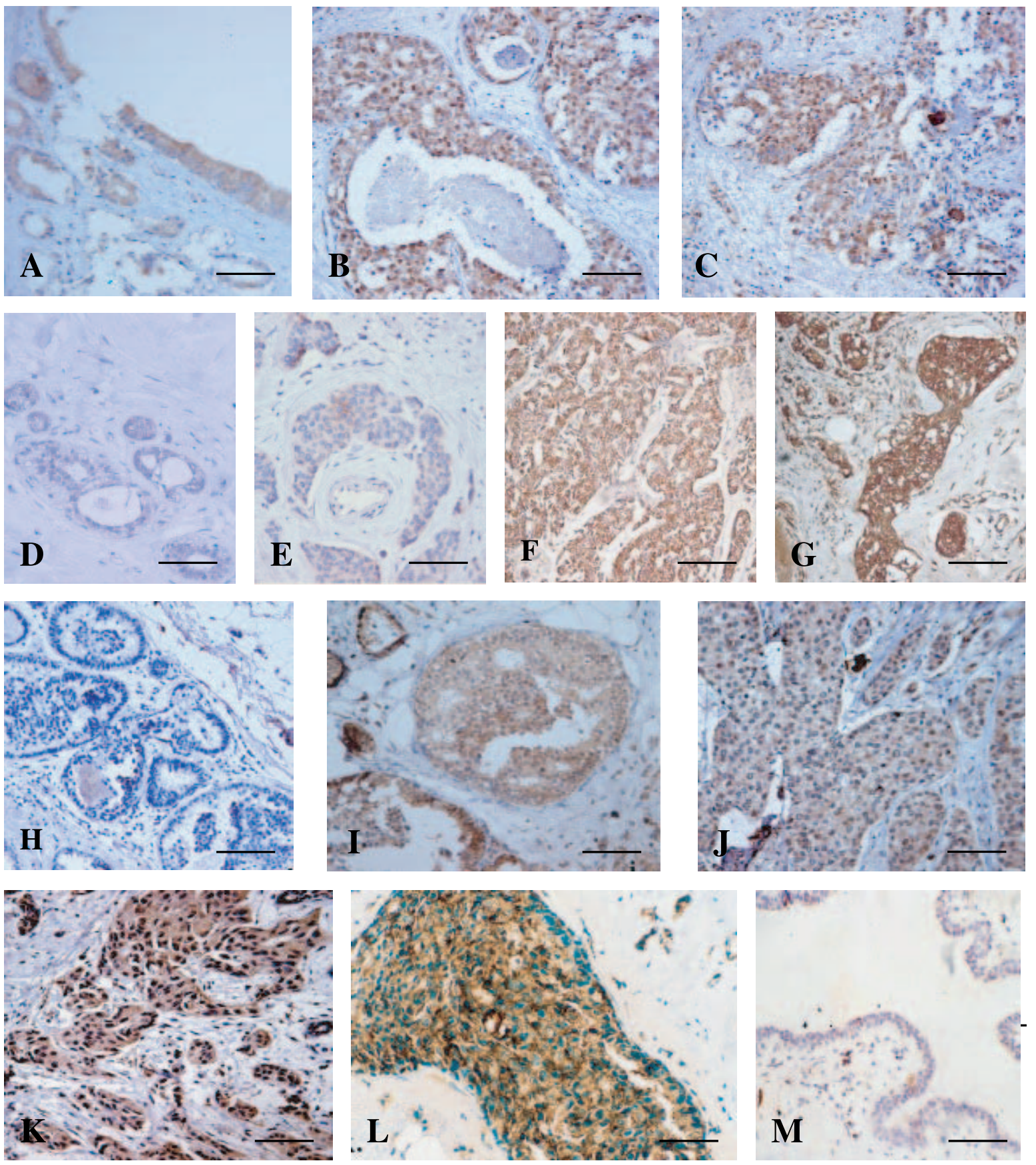

Figure 4 Representative immunohistochemical localisation of the ghrelin/GHSR axis in normal breast and breast cancer tissues. (A) Ghrelin immunoreactivity was present in normal breast where there were low levels of staining. (B,C) Higher levels of immunoreactivity were seen in low-grade carcinoma samples stained at the same time. (D) Low levels of immunoreactivity for the exon 3-deleted preproghrelin C-terminal peptide were demonstrated in normal breast tissue and (E) grade 1 carcinoma, whilst higher levels were seen in (F) grade 2 carcinoma and $(G)$ high-grade (grade 3 ) breast cancer. $(H)$ Representative negative control for GHSR 1a where the primary antiserum was omitted. (I) GHSR 1a staining was present in breast cancer grade 1, (J) grade 2, and (K) grade 3 breast cancer specimens. (L) GHSR 1 b immunostaining was strong in breast cancer tissues; however, there was no specific staining for GHSR $1 \mathrm{~b}$ in (M) normal breast tissue. Three independent tissue samples were stained for each antibody and tumour type, in at least three experiments each. Scale bars represent $100 \mu \mathrm{m}$ in $\mathrm{A}, \mathrm{D}, \mathrm{H}, \mathrm{I}$ and $\mathrm{M}$ and $50 \mu \mathrm{m}$ in $B, C, E, F, G$ and $J-L$. 
A

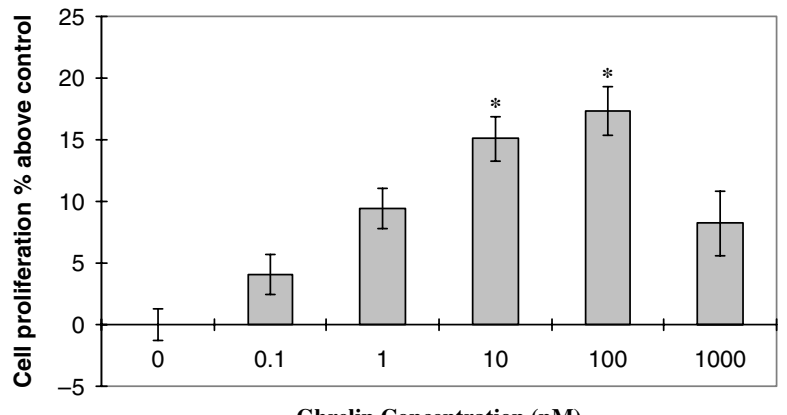

Ghrelin Concentration $(\mathrm{nM})$
B

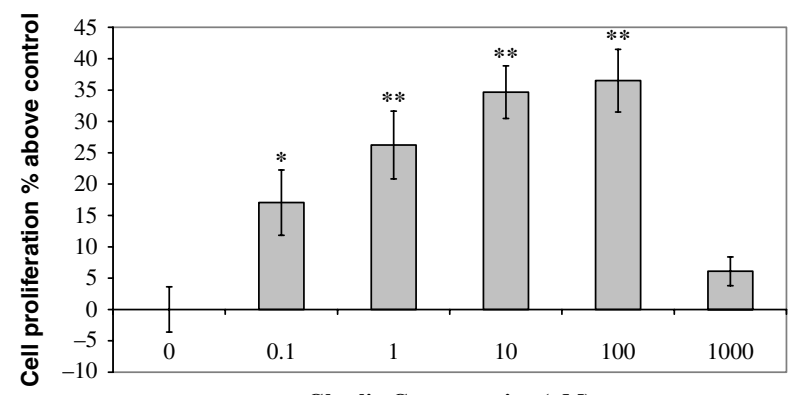

Ghrelin Concentration (nM)

Figure 5 Effect of $n$-octanoylated ghrelin on proliferation of MDA-MB-231 and MDA-MB-435 breast cancer cells in vitro. (A) Wst-1 proliferation assay performed on the MDA-MB-231 breast cancer cell line showing an increase in cell growth after treatment with increasing concentrations of ghrelin for $72 \mathrm{~h}$. Proliferation, represented as percentage absorbance above control, is significantly increased with 10 and $100 \mathrm{nM}$ ghrelin treatments $(P<0.05)$. (B) The MDA-MB-435 cell line proliferated faster in the presence of $0.1 \mathrm{nM}$ ghrelin $(P<0.05)$, and in the presence of 1,10 and $100 \mathrm{nM}$ ghrelin $(P<0.01)$, than in controls. All data represent the mean \pm S.E.M. of 3 experiments ( $n=16$ per treatment). ${ }^{\star} P<0.05,{ }^{\star \star} P<0.01$ relative to controls.

suggesting that the GHSR type $1 \mathrm{~b}$ isoform is not translated in normal breast tissue (Fig. 4M). The stromal tissue in the breast did not exhibit specific staining and negative controls also failed to show immunoreactivity for all antibodies used in this study (see Fig. 4H). Immunohistochemistry also demonstrated protein expression of the ghrelin/GHSR axis in breast cancer cell lines (data not shown).

\section{Wst-1 proliferation assays}

Cell proliferation assays were performed in the MDAMB-231, MDA-MB-435, MCF-7 and MCF-10A breast cancer cell lines with the addition of a range of concentrations of ghrelin $(0-1000 \mathrm{nM})$ for $72 \mathrm{~h}$. Growth rate of the MDA-MB-231 cells was significantly increased by approximately $15 \%$ when treated with $10 \mathrm{nM} n$-octanoylated ghrelin $(P=0.04)$ and $17 \%$ when treated with $100 \mathrm{nM}$ ghrelin $(P=0.04)$ when compared with controls receiving no ghrelin treatment (Fig. 5A). Ghrelin treatment also increased the rate of cell proliferation in the MDA-MB-435 cell line at $0.1 \mathrm{nM} \quad(P=0.04), \quad 1 \mathrm{nM} \quad(P=0.003)$ and $10 \mathrm{nM}$ $(P<0.001)$, with the greatest response seen at $100 \mathrm{nM}$ ghrelin treatment $(36 \%$ above control, $P<0.001)$ (Fig. 5B). Cell proliferation was not affected by ghrelin treatment $(0-1000 \mathrm{nM})$ in the MCF-10A or MCF-7 cell lines (data not shown).

\section{Discussion}

The data presented here suggest that ghrelin plays a role in breast cancer by stimulating cell proliferation, possibly via an autocrine/paracrine mechanism. This study is the first to report the expression of a new exon 3-deleted preproghrelin variant in the breast that is more highly expressed in breast cancer compared with normal breast tissues. We also report, for the first time, that GHSR $1 \mathrm{~b}$ is differentially expressed in normal breast tissue compared with breast cancer specimens. We have demonstrated the expression of ghrelin, exon 3-deleted preproghrelin, and GHSR 1a and $1 \mathrm{~b}$ in the MCF-7, MDA-MB-231, MDA-MB-435 and T47D breast cancer cell lines, in the nontumorigenic MCF-10A cell line and in a range of breast cancer tissues.

The potential tumour-promoting role of ghrelin is supported by our finding that ghrelin increases proliferation in breast cancer cell lines. Evidence provided here demonstrates that the addition of exogenous $n$-octanoylated ghrelin significantly stimulates proliferation in the highly metastatic MDA-MB-435 breast cancer cell line by up to $36 \%$ over controls and up to $17 \%$ above control in the oestrogen-independent MDA-MB-231 breast cancer cell line. An autocrine/ paracrine role for ghrelin in a wide-range of cancers has previously been proposed (Jeffery et al. 2003). Acylated ghrelin has been shown to stimulate proliferation of cancer cell lines including prostate cancer (Jeffery et al. 2002), HepG2 hepatoma cells (Murata et al. 2002) and rat GH3 pituitary somatotroph tumour cells (Nanzer et al. 2004). Proliferation was also attenuated by up to $40 \%$ in the human erythroleukaemic HEL cell line after endogenously produced ghrelin was apparently neutralised with an anti-ghrelin antibody (De Vriese et al. 2005). This cell line secretes 
substantial amounts of active ghrelin into culture medium (De Vriese et al. 2005), as does the TT thyroid carcinoma cell line (Kanamoto et al. 2001). Ghrelin may also have other roles in cancer, as ghrelin treatment increases the proliferative, migratory and invasive potential of pancreatic cancer cells. This potentially occurs via an autocrine/paracrine pathway, as these cells co-express ghrelin and the GHSR (Duxbury et al. 2003).

In contrast to our study, Cassoni and co-workers reported that treating MCF-7, MDA-MB-231 and T47D breast cancer cell lines with $1 \mu \mathrm{M}$ ghrelin significantly inhibited cell proliferation (Cassoni et al. 2001). We have demonstrated that the proliferative response to ghrelin increases at ghrelin concentrations of 10 and $100 \mathrm{nM}$ in the MDA-MB-231 cell line, and $0.1-100 \mathrm{nM}$ in the MDA-MB-435 cell line, which encompasses normal circulating ghrelin levels ( 0.1-1 nM; Kojima et al. 1999, Pemberton et al. 2003, Groschl et al. 2004). As the octanoylated form of ghrelin is highly unstable in normal assay conditions, AESBF can be used to prevent the rapid deacylation of ghrelin (Katugampola et al. 2001). There is no evidence that ghrelin was protected in the Cassoni studies and, as a result, des-acyl ghrelin may be produced causing a negative impact on cell growth, as has been observed in the des-acyl overexpressing mouse (Ariyasu et al. 2005).

The mechanism underlying ghrelin-induced proliferation in breast cancer is unknown, although it is likely to act by stimulating the mitogen-activated protein kinase pathway, as demonstrated in our own studies in the prostate (Yeh et al. 2005) and in similar studies in HepG2 cells (Murata et al. 2002), cardiomyocytes (Baldanzi et al. 2002), adrenal cells (Andreis et al. 2003, Mazzocchi et al. 2004), 3T3-L1 adipocytes (Kim et al. 2004) and rodent GH3 cells (Nanzer et al. 2004). Alternatively, ghrelin could act by stimulating $\mathrm{GH}$ secretion from the breast epithelium. GH appears to contribute to breast carcinogenesis by a variety of means, including the autocrine stimulation of cell proliferation and survival (Kaulsay et al. 2001), and therefore targeting autocrine/paracrine GH pathways could benefit breast cancer patients (Waters \& Conway-Campbell 2004). Enhancement of endogenous GH secretion may, at least partly, explain the proliferative effect of ghrelin on breast cancer cells in vitro that we have demonstrated here.

GHSR binding sites have been demonstrated previously in the MCF-7, MDA-MB-231 and T47D breast cancer cell lines, although the same study failed to demonstrate specific expression of GHSR type 1a mRNA using RT-PCR (Cassoni et al. 2001). In the present study, however, nested RT-PCR amplified both known isoforms of the GHSR in these cell lines. Cytoplasmic protein expression of the functional receptor was also detected in breast cancer tissues of varying pathological grades by immunohistochemistry. The presence of both ghrelin and GHSR 1a in breast cancer tissues strengthens the proposition that ghrelin stimulates cell proliferation in the breast via an autocrine/paracrine mechanism.

The immunohistochemical and PCR data presented here demonstrate that GHSR $1 \mathrm{~b}$ is highly expressed in breast cancer tissue with negligible expression in normal breast specimens. This is the first report of differential expression of the GHSR type $1 b$ isoform in the breast and this finding suggests that GHSR $1 \mathrm{~b}$ could represent a new marker for breast cancer. Similarly, GHSR 1b mRNA copy number is reported to be significantly higher in somatotroph adenomas compared with normal pituitary tissue (Korbonits et al. 2001), and mRNA for the GHSR type 1b isoform was not detectable in normal prostate cDNA, but abundantly expressed in prostate cancer cell lines (Jeffery et al. 2002). To date, there has been no function ascribed to this isoform of the receptor. In cells overexpressing the type $1 \mathrm{~b}$ isoform, the $\mathrm{GH}$ secretagogue, MK-0677, failed to bind GHSR $1 \mathrm{~b}$ or activate intracellular signalling through calcium release, as occurs with GHSR 1a (Howard et al. 1996). To our knowledge, binding and signalling studies have not been reported for the natural ligand, ghrelin.

Ghrelin is synthesised as a 117 amino acid prohormone, preproghrelin. The human ghrelin gene consists of 4 coding exons and a very recently identified non-coding exon located upstream of the coding region which corresponds to non-coding sequence in the mouse ghrelin gene (Nakai et al. 2004). However, we have based our nomenclature of the human preproghrelin variant on the coding exons only. The 28 amino acid mature ghrelin peptide is translated from the coding exon 1 and part of exon 2 (Kojima et al. 1999). The splicing out of exon 3 , therefore, does not interrupt the coding region of mature ghrelin itself, but alters the C-terminus of proghrelin by the introduction of a frameshift and an early stop codon. Thus, the C-terminus of exon 3-deleted preproghrelin consists of a unique peptide sequence of 16 amino acids and begins with a dibasic motif (RR), which may allow cleavage of the tail (Fig. 2). We have recently reported the expression profile of an homologous murine preproghrelin variant (Jeffery et al. 2005), suggesting that this conserved peptide may serve a functional role within the ghrelin axis. Using real-time RT-PCR, the present study demonstrates the overexpression of 
the exon 3-deleted isoform of preproghrelin in the MDA-MB-231 and MDA-MB-435 cell lines, which are derived from aggressive breast tumours, when compared with the benign MCF-10A cell line. Upregulated expression of the exon 3-deleted mRNA variant may be associated with increased malignant potential in breast cancer cells, as occurs with other mRNA transcripts borne of cancer-specific alternative splicing (Venables 2004). Correspondingly, protein expression of the unique exon 3-deleted preproghrelin was up-regulated in breast cancer specimens when compared with normal tissue. This indicates that elevated expression of the novel peptide may play a functional role in breast pathogenesis. A recent study identified immunoreactivity for C-terminal ghrelin peptides derived from the last 66 amino acids of native proghrelin in human serum and it is speculated that these $\mathrm{C}$-ghrelin peptides may have relevance in cardiovascular disease (Pemberton et al. 2003). Further studies are warranted to determine if the unique C-terminal peptide of exon 3-deleted preproghrelin is cleaved from the remaining proghrelin peptide and if it circulates in human plasma in substantial quantities.

In summary, this study has described the expression of the ghrelin axis, including a novel exon 3-deleted preproghrelin isoform, in breast cancer specimens and cell lines and reports functional evidence that the proliferative rate of breast cancer cell lines increases in response to ghrelin treatment. This suggests that blockade of the ghrelin axis may have some therapeutic benefit. Ghrelin, the novel exon-3 deleted preproghrelin isoform and the GHSR type $1 b$ isoform also display potential as diagnostic/prognostic markers for breast pathogenesis.

\section{Funding}

This work was supported by grants from the National Health and Medical Research Council of Australia and by the Queensland University of Technology. No conflict of interest prejudices the impartiality of this manuscript.

\section{References}

Anderson E \& Clarke RB 2004 Steroid receptors and cell cycle in normal mammary epithelium. Journal of Mammary Gland Biology and Neoplasia 9 3-13.

Andreis PG, Malendowicz LK, Trejter M, Neri G, Spinazzi R, Rossi GP \& Nussdorfer GG 2003 Ghrelin and growth hormone secretagogue receptor are expressed in the rat adrenal cortex: Evidence that ghrelin stimulates the growth, but not secretory activity of adrenal cells. FEBS Letters 536 173-179.

Ariyasu H, Takaya K, Iwakura H, Hosoda H, Akamizu T, Arai Y, Kangawa K \& Nakao K 2005 Transgenic mice overexpressing des-acyl ghrelin show small phenotype. Endocrinology 146 355-364.

Arnaldi G, Mancini T, Kola B, Appolloni G, Freddi S, Concettoni C, Bearzi I, Masini A, Boscaro M \& Mantero F 2003 Cyclical Cushing's syndrome in a patient with a bronchial neuroendocrine tumor (typical carcinoid) expressing ghrelin and growth hormone secretagogue receptors. Journal of Clinical Endocrinology and Metabolism 88 5834-5840.

Baldanzi G, Filigheddu N, Cutrupi S, Catapano F, Bonissoni S, Fubini A, Malan D, Baj G, Granata R, Broglio F et al. 2002 Ghrelin and des-acyl ghrelin inhibit cell death in cardiomyocytes and endothelial cells through ERK1/2 and PI 3-kinase/AKT. Journal of Cell Biology 159 1029-1037.

Barreiro ML \& Tena-Sempere M 2004 Ghrelin and reproduction: a novel signal linking energy status and fertility? Molecular and Cellular Endocrinology 226 1-9.

Cassoni P, Papotti M, Ghe C, Catapano F, Sapino A, Graziani A, Deghenghi R, Reissmann T, Ghigo E \& Muccioli G 2001 Identification, characterization and biological activity of specific receptors for natural (ghrelin) and synthetic growth hormone secretagogues and analog in human breast carcinoma and cell lines. Journal of Clinical Endocrinology and Metabolism 86 1738-1745.

Corbetta S, Peracchi M, Cappiello V, Lania A, Lauri E, Vago L, Beck-Peccoz P \& Spada A 2003 Circulating ghrelin levels in patients with pancreatic and gastrointestinal neuroendocrine tumors: identification of one pancreatic ghrelinoma. Journal of Clinical Endocrinology and Metabolism 88 3117-3120.

De Vriese C, Gregoire F, De Neef P, Robberecht P \& Delporte C 2005 Ghrelin is produced by the human erythroleukemic HEL cell line and involved in an autocrine pathway leading to cell proliferation. Endocrinology 146 1514-1522.

Duxbury MS, Waseem T, Ito H, Robinson MK, Zinner MJ, Ashley SW \& Whang EE 2003 Ghrelin promotes pancreatic adenocarcinoma cellular proliferation and invasiveness. Biochemical and Biophysical Research Communications 309 464-468.

Ellison G, Klinowska T, Westwood RF, Docter E, French T \& Fox JC 2002 Further evidence to support the melanocytic origin of MDA-MB-435. Molecular Pathology 55 294-299.

Feighner SD, Howard AD, Prendergast K, Palyha O, Hreniuk DL, Nargund R, Underwood D, Tata JR, Dean DC, Tan CP et al. 1998 Structural requirements for the activation of the human growth hormone secretagogue receptor by peptide and non-peptide secretagogues. Molecular Endocrinology 12 137-145.

Gaytan F, Barreiro ML, Caminos JE, Chopin LK, Herington AC, Morales C, Pinilla L, Paniagua R, Nistal M, 
Casanueva FF et al. 2004 Expression of ghrelin and its functional receptor, the type 1a growth hormone secretagogue receptor, in normal human testis and testicular tumours. Journal of Clinical Endocrinology and Metabolism 89 400-409.

Groschl M, Uhr M \& Kraus T 2004 Evaluation of the comparability of commercial ghrelin assays. Clinical Chemistry 50 457-458.

Hosoda H, Kojima M, Matsuo H \& Kangawa K 2000 Ghrelin and des-acyl ghrelin: two major forms of rat ghrelin peptide in gastrointestinal tissue. Biochemical and Biophysical Research Communications 279 909-913.

Howard AD, Feighner SD, Cully DF, Arena JP, Liberator PA, Rosenblum CI, Hamelin M, Hreniuk DL, Palyha OC, Anderson J et al. 1996 A receptor in pituitary and hypothalamus that functions in growth hormone release. Science 273 974-977.

Iwakura H, Hosoda K, Doi R, Komoto I, Nishimura H, Son C, Fujikura J, Tomita T, Takaya K, Ogawa Y et al. 2002 Ghrelin expression in islet cell tumors: augmented expression of ghrelin in a case of glucagonoma with multiple endocrine neoplasm type I. Journal of Clinical Endocrinology and Metabolism 87 4885-4888.

Jeffery P, Herington A \& Chopin L 2002 Expression and action of the growth hormone releasing peptide ghrelin and its receptor in prostate cancer cell lines. Journal of Endocrinology 172 7-11.

Jeffery PL, Herington AC \& Chopin LK 2003 The potential autocrine/paracrine roles of ghrelin and its receptor in hormone-dependent cancer. Cytokine and Growth Factor Reviews 14 113-122.

Jeffery PL, Duncan RP, Yeh AH, Jaskolski RA, Hammond DS, Herington AC \& Chopin LK 2005 Expression of the ghrelin axis in the mouse: an exon 4-deleted mouse proghrelin variant encodes a novel C-terminal peptide. Endocrinology 146 432-440.

Jemal A, Tiwari RC, Murray T, Ghafoor A, Samuels A, Ward E, Feuer EJ \& Thun MJ 2004 Cancer statistics, 2004. CA: A Cancer Journal for Clinicians 54 8-29.

Kanamoto N, Akamizu T, Hosoda H, Hataya Y, Ariyasu H, Takaya K, Hosoda K, Saijo M, Moriyama K, Shimatsu A et al. 2001 Substantial production of ghrelin by a human medullary thyroid carcinoma cell line. Journal of Clinical Endocrinology and Metabolism 86 4984-4990.

Katugampola SD, Pallikaros Z \& Davenport AP 2001 [ ${ }^{125} \mathrm{I}-$ His(9)]-ghrelin, a novel radioligand for localizing GHS orphan receptors in human and rat tissue: up-regulation of receptors with atherosclerosis. British Journal of Pharmacology 134 143-149.

Kaulsay KK, Zhu T, Bennett W, Lee KO \& Lobie PE 2001 The effects of autocrine human growth hormone (hGH) on human mammary carcinoma cell behaviour are mediated via the hGH receptor. Endocrinology 142 767-777.

Kim MS, Yoon CY, Jang PG, Park YJ, Shin CS, Park HS, Ryu JW, Pak YK, Park JY, Lee KU et al. 2004 The mitogenic and antiapoptotic actions of ghrelin in 3T3-L1 adipocytes. Molecular Endocrinology 18 2291-2301.
Kojima M, Hosodo H, Date Y, Nakazato M, Matsuo H \& Kanagawa K 1999 Ghrelin is a growth hormone releasing acylated peptide from stomach. Nature 402 656-660.

Korbonits M, Bustin SA, Kojima M, Jordan S, Adams EF, Lowe DG, Kangawa K \& Grossman AB 2001 The expression of the growth hormone secretagogue receptor ligand ghrelin in normal and abnormal human pituitary and other neuroendocrine tumors. Journal of Clinical Endocrinology and Metabolism 86 881-887.

Laban C, Bustin SA \& Jenkins PJ 2003 The GH-IGF-I axis and breast cancer. Trends in Endocrinology and Metabolism 14 28-34.

Maccarinelli G, Sibilia V, Torsello A, Raimondo F, Pitto M, Giustina A, Netti C \& Cocchi D 2005 Ghrelin regulates proliferation and differentiation of osteoblastic cells. Journal of Endocrinology 184 249-256.

Mazzocchi G, Neri G, Rucinski M, Rebuffat P, Spinazzi R, Malendowicz LK \& Nussdorfer GG 2004 Ghrelin enhances the growth of cultured human adrenal zona glomerulosa cells by exerting MAPK-mediated proliferogenic and antiapoptotic effects. Peptides 25 1269-1277.

Murata M, Okimura Y, Iida K, Matsumoto M, Sowa H, Kaji H, Kojima M, Kangawa K \& Chihara K 2002 Ghrelin modulates the downstream molecules of insulin signaling in hepatoma cells. Journal of Biological Chemistry 277 5667-5674.

Nakai N, Kaneko M, Nakao N, Fujikawa T, Nakashima K, Ogata M \& Tanaka M 2004 Identification of promoter region of ghrelin gene in human medullary thyroid carcinoma cell line. Life Sciences 75 2193-2201.

Nanzer AM, Khalaf S, Mozid AM, Fowkes RC, Patel MV, Burrin JM, Grossman AB \& Korbonits M 2004 Ghrelin exerts a proliferative effect on a rat pituitary somatotroph cell line via the mitogen-activated protein kinase pathway. European Journal of Endocrinology 151 223-240.

Papotti M, Ghe C, Cassoni P, Catapano F, Deghenghi R, Ghigo E \& Muccioli G 2000 Growth hormone secretagog binding sites in peripheral human tissues. Journal of Clinical Endocrinology and Metabolism $\mathbf{8 5}$ 3803-3807.

Papotti M, Cassoni P, Volante M, Deghenghi R, Muccioli G \& Ghigo E 2001 Ghrelin producing endocrine tumors of the stomach and intestine. Journal of Clinical Endocrinology and Metabolism 86 5052-5059.

Pemberton C, Wimalasena P, Yandle T, Soule S \& Richards M 2003 C-terminal proghrelin peptides are present in the human circulation. Biochemical and Biophysical Research Communications 310 567-573.

Pettersson I, Muccioli G, Granata R, Deghenghi R, Ghigo E, Ohlsson C \& Isgaard J 2002 Natural (ghrelin) and synthetic (hexarelin) GH secretagogues stimulate H9c2 cardiomyocyte cell proliferation. Journal of Endocrinology 175 201-209.

Sellappan S, Grijalva R, Zhou X, Yang W, Eli MB, Mills GB \& Yu D 2004 Lineage infidelity of MDA-MB-435 cells: expression of melanocyte proteins in a breast cancer cell line. Cancer Research 64 3479-3485. 
Soule HD, Maloney TM, Wolman SR, Peterson WD Jr, Brenz R, McGrath CM, Russo J, Pauley RJ, Jones RF \& Brooks SC 1990 Isolation and characterization of a spontaneously immortalized human breast epithelial cell line, MCF-10. Cancer Research 50 6075-6086.

Tsolakis AV, Portela-Gomes GM, Stridsberg M, Grimelius L, Sundin A, Eriksson BK, Oberg KE \& Janson ET 2004 Malignant gastric ghrelinoma with hyperghrelinemia. Journal of Clinical Endocrinology and Metabolism 89 3739-3744.

Venables JP 2004 Aberrant and alternative splicing in cancer. Cancer Research 64 7647-7654.

Volante M, Allia E, Fulcheri E, Cassoni P, Ghigo E, Muccioli G \& Papotti M 2003 Ghrelin in fetal thyroid and follicular tumors and cell lines: expression and effects on tumor growth. American Journal of Pathology 162 645-654.

Waters MJ \& Conway-Campbell BL 2004 The oncogenic potential of autocrine human growth hormone in breast cancer. PNAS 101 14992-14993.
Wren AM, Seal LJ, Cohen MA, Brynes AE, Frost GS, Murphy KG, Dhillo WS, Ghatei MA \& Bloom SR 2001 Ghrelin enhances appetite and increases food intake in humans. Journal of Clinical Endocrinology and Metabolism 86 5992-5995.

Yeh AH, Jeffery PL, Duncan RP, Herington AC \& Chopin LK 2005 Ghrelin and a novel preproghrelin isoform are highly expressed in prostate cancer compared to normal prostate tissue and ghrelinmediated prostate cancer cell line proliferation involves the MAPK pathway. Clinical Cancer Research (in press).

Zhang W, Zhao L, Lin TR, Chai B, Fan Y, Gantz I \& Mulholland MW 2004a Inhibition of adipogenesis by ghrelin. Molecular Biology of the Cell 15 2484-2491.

Zhang W, Lin TR, Hu Y, Fan Y, Zhao L, Stuenkel EL \& Mulholland MW $2004 b$ Ghrelin stimulates neurogenesis in the dorsal motor nucleus of the vagus. Journal of Physiology 559 729-737. 